\title{
Australian Journal of

\section{Production of mint under planting densities of mung bean (Vigna radiata) in loam argisol yellow red latosol}

\author{
Ariana Morais Neves ${ }^{1}$, Paulo César Ferreira Linhares ${ }^{1 *}$, Lunara de Sousa Alves ${ }^{2}$, Roberto Pequeno de \\ Sousa ${ }^{1}$, Janilson Pinheiro de Assis ${ }^{1}$, Maria Francisca Soares Pereira ${ }^{1}$, Rogério Alexandrino da Silva ${ }^{1}$, Rita \\ lanáskara Gomes da Silva ${ }^{1}$, Jordany Ramalho Silveira Farias ${ }^{3}$, Eudes de Almeida Cardoso ${ }^{1}$
}

\author{
${ }^{1}$ Federal Rural Semi-Arid University, Department of Agronomic and Forestry Sciences, Jitirana Research Group, \\ Mossoró-RN, 59625-900, Brazil \\ ${ }^{2}$ Federal University of Paraiba, Campus Areia, Areia-PB, 58397-000, Brazil \\ ${ }^{3}$ Process Engineering (CCT), Federal University of Campina Grande, Brazil
}

\section{*Corresponding author: paulolinhares@ufersa.edu.br}

\begin{abstract}
The use of legumes as fertilizer haqs been a viable option for the farmers who work in the production of medicinal plants with agroecological management. In this sense, the objective was to evaluate the production of mint under planting densities of mung bean in loam argisol yellow red latosol. The experiment was conducted at the Rafael Fernandes Experimental Farm, in the Alagoinha district, rural area of Mossoró, RN, Brazil, from August 2016 to March 2017. The experimental design was randomized complete blocks with the treatments arranged in $4 \times 2$ factorial scheme with three replicates. The first factor consisted of sowing densities (50; 100; 150 and 200 plants $\mathrm{m}^{-2}$ ) and the second factor was management systems such as incorporation and permanence (covered) of mung bean biomass on the soil surface. The cultivar "Mentha piperita" was used for the mint crop. The evaluated characteristics were the following: biomass height, green mass production, number of bunches, dry mass production, oil content and oil production of mint. The sowing density of 150 plants $\mathrm{m}^{-2}$ of mung bean provided production and number of mint bunches of $2.63 \mathrm{~kg} \mathrm{~m}^{-2}$ and 26.3 units $\mathrm{m}^{-2}$, respectively. For the forms of biomass management (incorporated and covered), no statistical difference was observed for the characteristics of the production of green mass, number of bunches, content and oil production of mint. The use of mung bean as a green manure for mint production is feasible to be used by farmers in northeastern Brazil.
\end{abstract}

Keywords: green manuring, Mentha piperita (L.), medicinal plant, agroecological production. Abbreviations: DAE_days after sowing; DAT_days after transplanting.

Introduction

A very popular practice in family farming is the production of vegetables and herbs in diversified forms, which consists of the production of various horticultural and medicinal species destined for commercialization and subsistence (Cunha et al., 2018). The cultivation of medicinal plants is of great importance due to the demand exerted by the industries chemical, pharmaceutical, food and cosmetic product. Within the genus Mentha, belonging to the Family Lamiaceae, Mentha piperita is popularly known, mainly for the commercial exploitation of essential oil extracted from its aerial part and also for the medicinal use in the combat of stomach disorders, respiratory apparatus and intestinal parasites (Chagas et al., 2011). One of the factors that interfere in the production of biomass and essential oil is soil fertility, since soil nutritional conditions are essential for the nutritional balance of the Mentha crop (Valmorbida et al., 2006). Vegetative growth of mint is a pre-potentiating factor in plant productivity, considering that the storage of essential oil occurs in pelicular glandular trichomes found in the (Wildung and Croteau, 2005). In the region of Mossoró, Northeast Brazil, the most used fertilizer source is manure, which limits production, since the farmer does not have availability of this organic waste throughout the year, contributing to the increase in production costs (Linhares et al., 2014). In this context, green manure is an alternative to the farmer in terms of the benefits it provides, such as: improved physical, chemical and biological conditions. In this practice, the most used species are legumes, responsible for the fixation of atmospheric nitrogen in the soil through symbiosis with bacteria of the genus Rhizobium, besides the high production of green and dry phytomass (Linhares, 2013). In addition, these species present phosphorus, potassium, calcium and especially nitrogen contents, given the symbiotic $\mathrm{N}$ fixation by the bacteria belonging to the genus Rhizobium that develop in their roots (Tavares Junior et al., 2015). Mung bean (Vigna radiata L.) is a legume with characteristics desirable to be used as green manure, fast growing plant, short cycle, and low soil fertility requirement 
(Ambrosano et al., 2014). Neves et al. (2018) studied the agronomic productivity of lettuce, fertilized with mung bean in the presence and absence of bovine manure, found production of $170 \mathrm{~kg} 100 \mathrm{~m}^{-2}$. Due to the importance of searching for alternatives that make the use of green manure in the production of vegetables feasible, the objective of this study was to evaluate the production of mint under planting densities of mung bean in loam argisol yellow red latosol.

\section{Results}

The data in Table 1, expresses the analysis of the variance of the characteristics biomass height, production of mint, number of bunches, dry mass, oil content and oil production of mint at 60 DAT.

\section{Biomass height, green mass production and number of bunches}

For height of the mint biomass, there was no statistical difference in planting densities, with an average value of $28.4 \mathrm{~cm}$. For biomass management, similar behavior occurred, with mean values of 28.6 and $28.1 \mathrm{~cm}$, respectively.

For the green mass production and number of bunches, there was a maximum point, with $2.63 \mathrm{~kg} \mathrm{~m}^{-2}$ of mint, equivalent to 26.3 units $\mathrm{m}^{-2}$ at the density of 150 plants $\mathrm{m}^{-2}$ of mung bean (Figure $1 \mathrm{~A}$ and $1 \mathrm{~B}$ ). There was an average increase of $1.1 \mathrm{~kg} \mathrm{~m}^{-2}$ of fresh mint mass between the highest (150 plants $\mathrm{m}^{-2}$ ) and lowest (50 plants $\mathrm{m}^{-2}$ ) planting density. Among the forms of biomass management (incorporated and covered), there was no statistical difference in mean values of 2.1 and $1.9 \mathrm{~kg} \mathrm{~m}^{-2}$, for green mass production and 21.0 and 19.0 units $\mathrm{m}^{-2}$, for number bunches, respectively.

\section{Dry mass production, oil content and oil production of mint}

There was an increase of $0.43 \mathrm{~kg} \mathrm{~m}^{-2}$ between the planting densities of 50 plants $\mathrm{m}^{-2}\left(0.26 \mathrm{~kg} \mathrm{~m}^{-2}\right)$ and 200 plants $\mathrm{m}^{-2}$ $\left(0.43 \mathrm{~kg} \mathrm{~m}^{-2}\right)$ in the dry mass (Figure 2). There were no statistical differences in the management (incorporated and covered), with mean values of 0.30 and $0.35 \mathrm{~kg} \mathrm{~m}^{-2}$, respectively. For oil content and production, there was a maximum pont, with values of $3.44 \mathrm{~g} \mathrm{~kg}^{-1}$ (content) and $1.24 \mathrm{~g} \mathrm{~m}^{-2}$ (production), at densities of 150 and 200 plants $\mathrm{m}^{-}$ 2 (Figures 3 and 4). The management of mung bean biomass (incorporated and covered) presented statistical similarity for the content and production of peppermint oil, with mean values of 2.8 and $3.3 \mathrm{~g} \mathrm{~kg}^{-1}$ (content) and 0.96 and $1.03 \mathrm{~g} \mathrm{~m}^{-2}$ (production), respectively.

\section{Discussion}

The use of the mung bean as a fertilizer contributed to the increase in the evaluated characteristics since this practice is very effective in the incorporation of nitrogen in the soil. Souza et al. (2012) described the benefits of this agricultural practice, the increase and stability of organic matter, exerting beneficial in the soil, contributing to the improvement of physical, chemical and biological properties.

\section{Effect of sowing density}

Cunha et al. (2018) reported a value of $21.76 \mathrm{~cm}$ for height of mint, when intercropped with coriander under organic fertilization. This value was inferior to that found in this research. This difference in value may be related to the type of fertilizer, in promoting edaphic conditions for the development of mint. Vicente et al. (2008), evaluated the production of medicinal plants using filter cake and they found average height of $45 \mathrm{~cm}$ for mint, superior to this research. Probably the harvest at 240 days after sowing has contributed to expressive height.

The superiority of sowing density of 50 plants $\mathrm{m}^{-2}$ is probably due to the higher phytomass production available in the soil (3.6 $\mathrm{kg} \mathrm{m}^{-2}$ ), compared to other densities, contributing to a greater availability of nutrients in the soil. In addition, the species is quite labile with a nitrogen-carbon ratio of 19/1, allowing a rapid degradation process, with potential of adding nitrogen to the soil. Cunha et al. (2018) found small value of $56.4 \mathrm{~kg} 100 \mathrm{~m}^{-2}$ for mint, equivalent to $0.56 \mathrm{~kg} \mathrm{~m}^{-2}$ when it is intercropped with coriander under organic fertilization. Likewise, Guerra et al. (2015) found a value of $0.55 \mathrm{~kg} \mathrm{~m}^{-2}$ of mint, equivalent to 5.0 sauces in intercropping with lettuce. Possibly the interspecific competition for biological resources (water and nutrients), contributed to a short production in the present research.

Cunha et al. (2018) studied agronomic efficiency of different quantities of jitirana mixed with cattle manure in the intercropping of coriander with mint, with dry mass of 6.56 $\mathrm{kg} 100 \mathrm{~m}^{-2}$, equivalent to $0.656 \mathrm{~kg} \mathrm{~m}^{-2}$ in the quantity of 3.0 $\mathrm{kg} \mathrm{m}^{-2}$, lower than the present study. The dry mass is a characteristic that reflects the growth of the vegetable (Taiz and Zeiger, 2017).

The period of the permanence of the plants in the field is associated with the content of essential oil and for $M$. piperita, a harvesting can be carried out between 60 and 120 days (Valmorbida et al., 2006). Chagas et al. (2011) studied organic fertilization in Japanese mint. They found an oil yield equivalent to $3.0 \mathrm{~g} \mathrm{~m}^{-2}$, higher than the present study. Deschamps et al. (2012), states that the largest amount of essential oil for Mentha $x$ piperita L., is between 60 and 120 days.

\section{Effect of biomass management of mung bean (Vigna radiata $\mathrm{L}$.)}

The absence of statistical difference in the biomass management factor in the evaluated characteristics is probably due to the degradation capacity of the vegetal mass in coverage, where it provides nutrients and edaphic conditions that resemble the incorporation of the material. According to Resende et al. (2005), the advantages of mulching can be understood from the maximization of the germination of the seeds to the maintenance of the appropriate conditions of temperature and soil moisture necessary for the optimal development of the plants. 
Table 1. F values for biomass height (BH), production of mint (PM), number of bunches (NB), dry mass (DM), oil content (OC) and oil production of mint (OP) under planting densities of mung bean (Vigna radiata) in loam argisol yellow red latosol.

\begin{tabular}{|c|c|c|c|c|c|c|c|}
\hline Causes of variation & GL & $\mathrm{BH}$ & PM & NB & DM & $\mathrm{OC}$ & OP \\
\hline Sowing density (S) & 3 & $2.6^{\mathrm{ns}}$ & $6.2^{* *}$ & $6.9^{* *}$ & $5.4^{*}$ & $3.3^{\text {ns }}$ & $12.9^{* *}$ \\
\hline $\begin{array}{l}\text { Management of mung bean } \\
\text { biomass (M) }\end{array}$ & 1 & $0.7^{\mathrm{ns}}$ & $0.65^{\text {ns }}$ & $1.1^{\mathrm{ns}}$ & $2.1^{\mathrm{ns}}$ & $3.0^{\text {ns }}$ & $0.6^{\mathrm{ns}}$ \\
\hline$A \times B$ & 3 & $1.6^{\mathrm{ns}}$ & $0.41^{\text {ns }}$ & $0.7^{\mathrm{ns}}$ & $7.2^{\text {ns }}$ & $0.7^{\mathrm{ns}}$ & $1.2^{\mathrm{ns}}$ \\
\hline Treatments & 7 & --- & --- & --- & --- & --- & --- \\
\hline Bloks & 2 & $1.6^{\mathrm{ns}}$ & $5.1^{*}$ & $10.2^{* *}$ & $7.2^{* *}$ & $1.7^{\mathrm{ns}}$ & $5.8^{*}$ \\
\hline Waste & 14 & -- & --- & --- & --- & --- & --- \\
\hline CV (\%) & --- & 13.7 & 19.4 & 16.8 & 18.3 & 13.5 & 11.6 \\
\hline
\end{tabular}

(A)

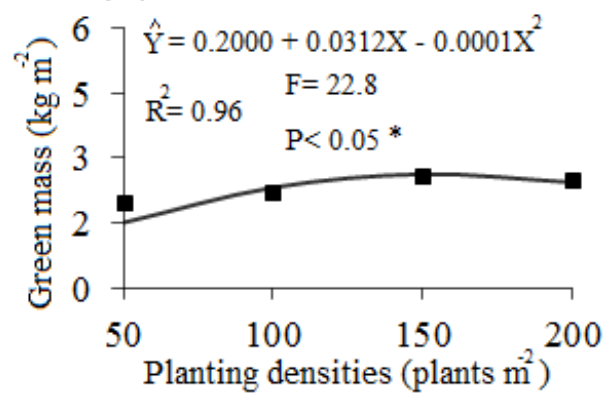

(B)

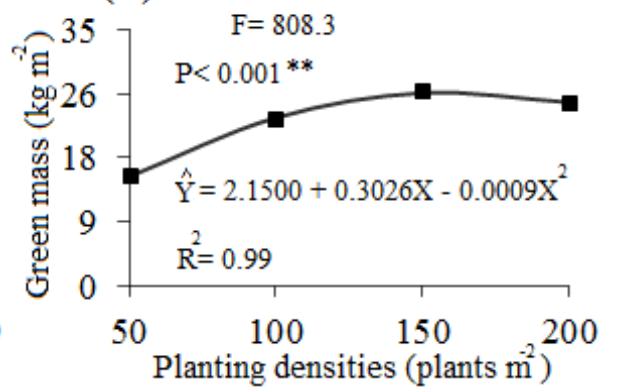

Fig 1. Production of green mass of mint $(A)$ and number of bunches (B) in function of planting densities of mung bean (Vigna radiata L.).

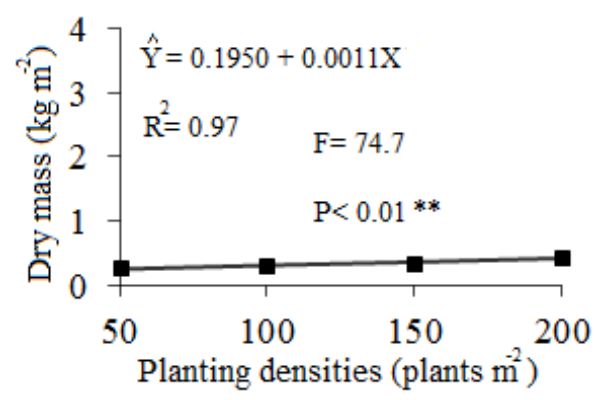

Fig 2. Dry mass of mint in function of planting densities of mung bean (Vigna radiata L.).

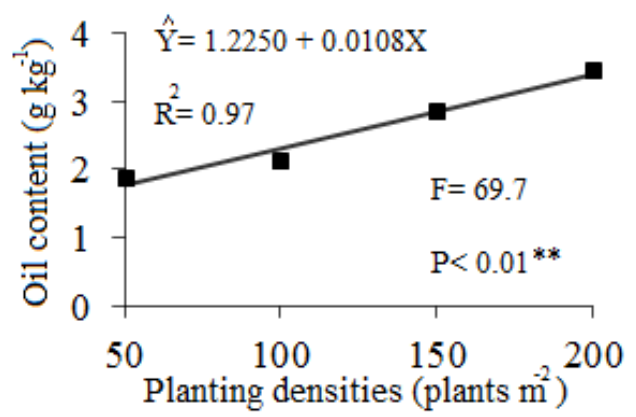

Fig 3. Oil content of mint in function of planting densities of mung bean (Vigna radiata L.). 


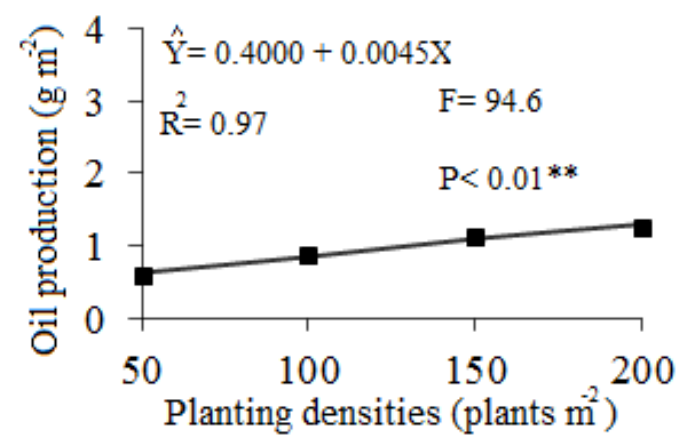

Fig 4. Oil production of mint in function of planting densities of mung bean (Vigna radiata L.).

\section{Materials and methods}

\section{Plant materials}

The study was conducted in the research area of the Rafael Fernandes Experimental Farm of the Federal Rural Semi-Arid University (UFERSA), from august 2016 to march 2017, located in the Alagoinha district, $20 \mathrm{~km}$ from the Mossoró, Northeastern Brazil. The farm comprises of 400 hectares (Rêgo et al., 2016).

According to Kottek et al. (2006) and the classification of Köppen, the local climate is BSwh ', dry and very hot. The dry season is normally from June to January, and a rainy season from February to May. The average annual rainfall is 673.9 $\mathrm{mm}$ and the average relative humidity is $68.9 \%$. The soil of the research area was classified as sandy loam Argisol Yellow Red Latosol (Embrapa, 2006).

Before the installation of field experiment, soil samples were collected to a $0-20 \mathrm{~cm}$ layer and then sent to be processed and analyzed in the UFERSA Water, Soil and Plant Analysis Laboratory, providing the following results: $\mathrm{pH}$ (water 1:2.5) = 6.80; exchangeable cations $\mathrm{Ca}=1.12 \mathrm{cmol}_{\mathrm{C}} \mathrm{dm}^{-3} ; \mathrm{Mg}=0.30$ $\mathrm{cmol}_{\mathrm{c}} \mathrm{dm}^{-3} ; \mathrm{K}=1.17 \mathrm{cmol}_{\mathrm{c}} \mathrm{dm}^{-3} ; \mathrm{Na}=0.22 \mathrm{cmol}_{\mathrm{c}} \mathrm{dm}^{-3} ; \mathrm{P}$ (Mehlich) $=2.30 \mathrm{mg} \mathrm{dm}^{-3}$; organic matter $=2.65 \mathrm{~g} \mathrm{~kg}^{-1}$; Coarse sand $=610 \mathrm{~g} \mathrm{~kg}^{-1}$; fine sand $=290 \mathrm{~g} \mathrm{~kg}^{-1}$; silte $=20 \mathrm{~g}$ $\mathrm{kg}^{-1}$; clay $=70 \mathrm{~g} \mathrm{~kg}^{-1}$, soil density $=1.42 \mathrm{~g} \mathrm{~cm}^{-3}$; particle density $=2.43 \mathrm{~g} \mathrm{~cm}^{-3}$ and Porosity $=0.42 \mathrm{~cm}^{3} \mathrm{~cm}^{-3}$.

\section{Statistical delineation and treatments}

The experimental design was randomized complete blocks with the treatments arranged in $4 \times 2$ factorial scheme, with three replicates. The first factor consisted of sowing densities (50; 100; 150 and 200 plants $\mathrm{m}^{-2}$ ) and the second factor consisted of the incorporation and permanence (coverage) in the soil surface of mung bean biomass. For the mung bean (incorporated and coverage) biomass management. The cultivar "Mentha piperita" was used for the mint crop. The study plots were $1.4 \mathrm{~m} \times 1.4 \mathrm{~m}$, with a total area of $1.96 / \mathrm{m}^{2}$, with 40 plants in each, spaced $0.35 \mathrm{~m}$ $x 0.2 \mathrm{~m}$, respectively. Therefore, the yielding area was 1.26 $\mathrm{m}^{-2}$, with 18 plants.

\section{Conduction of the experiment and use of the mung bean}

The soil preparation consisted of manual cleaning of the experimental area with the aid of a hoe, followed by harrowing and the construction of the beds, using as a mechanized rotary tool. During the experiment installation, $1.0 \mathrm{~kg} \mathrm{~m}^{-2}$ of bovine manure was incorporated into the soil in all experimental plots, with a concentration of $18.5 \mathrm{~g} \mathrm{~kg}^{-1}$ of nitrogen (N), $879 \mathrm{~g} \mathrm{~kg}^{-1}$ organic matter (OM); $401 \mathrm{~g} \mathrm{~kg}^{-1}$ of organic carbon $(O C) ; 22 / 1$ of carbon/nitrogen ratio $(\mathrm{C} / \mathrm{N})$; $0.68 \mathrm{~g} \mathrm{~kg}^{-1}$ of phosphorus (P); $5.87 \mathrm{~g} \mathrm{~kg}^{-1}$ of potassium $\left(\mathrm{K}^{+}\right)$; $0.70 \mathrm{~g} \mathrm{~kg}^{-1}$ of sodium $\left(\mathrm{Na}^{+}\right) ; 0.23 \mathrm{~g} \mathrm{~kg}^{-1}$ of calcium $\left(\mathrm{Ca}^{2+}\right)$ and $0.05 \mathrm{~g} \mathrm{~kg}^{-1}$ of magnesium $\left(\mathrm{Mg}^{2+}\right)$, carried out in the soil fertility and plant nutrition laboratory of the agrarian science center of the Federal Rural University of the semi-arid.

Before planting the mint, mung bean (Vigna radiata $\mathrm{L}$.) were seeded in the experimental plots in spacing of $0.20 \mathrm{~m} \times 0.10$ $\mathrm{m}$, with sowing of five to seven cova-1 seeds. Twelve days after sowing (DAE), thinning was done, leaving the number of plants according to planting density $(50 ; 100 ; 150$ and 200 plants $\mathrm{m}^{-2}$ ).

The mung bean was harvested 42 DAE at beginning of the flowering period, with phytomass production of $1.2 \mathrm{~kg} \mathrm{~m}^{-2}$ (50 plants $\left.\mathrm{m}^{-2}\right) ; 2.2 \mathrm{~kg} \mathrm{~m}^{-2}$ (100 plants $\left.\mathrm{m}^{-2}\right) ; 3.6 \mathrm{~kg} \mathrm{~m}^{-2}$ (150 plants $\mathrm{m}^{-2}$ ) and $3.0 \mathrm{~kg} \mathrm{~m}^{-2}$ (200 plants $\left.\mathrm{m}^{-2}\right)$. The plant material was sent to the soil fertility and plant nutrition, laboratory of the Agrarian science center of the Federal Rural University of the semi-arid, with chemical concentration of $18.5 \mathrm{~g} \mathrm{~kg}^{-1}$ of nitrogen (N); $780 \mathrm{~g} \mathrm{~kg}^{-1}$ organic matter (OM); $356 \mathrm{~g} \mathrm{~kg}^{-1}$ of organic carbon (OC); 19/1 of carbon/nitrogen ratio $(\mathrm{C} / \mathrm{N}) ; 0.68 \mathrm{~g} \mathrm{~kg}^{-1}$ of phosphorus $(\mathrm{P})$; $5.87 \mathrm{~g} \mathrm{~kg}^{-1}$ of potassium $\left(\mathrm{K}^{+}\right) ; 1.45 \mathrm{~g} \mathrm{~kg}^{-1}$ of sodium $\left(\mathrm{Na}^{+}\right)$; $0.23 \mathrm{~g} \mathrm{~kg}^{-1}$ of calcium $\left(\mathrm{Ca}^{2+}\right)$ and $0.05 \mathrm{~g} \mathrm{~kg}^{-1}$ of magnesium $\left(\mathrm{Mg}^{2+}\right)$.

The seedlings mint were transplanted after being grown in a greenhouse for 15 days, with $50 \%$ shading, with $10 \mathrm{~cm}$ in height.

\section{Harvesting and evaluation of the characteristics studied}

The harvest was performed 60 days after transplanting (DAT). After harvesting, plants were transported to the PostHarvest Vegetables Laboratory of the Agrarian Science Center of the Federal Rural University of the semi-arid.

The following characteristics were evaluated: biomass height (was measured in the field, in centimeters using millimeter ruler, twenty plants per plot), green mass production (It was obtained through the cut of the aerial part, above $5 \mathrm{~cm}$, within the useful area, weighed in a precision scale of $1.0 \mathrm{~g}$, expressed in $\mathrm{kg} \mathrm{m}^{-2}$ ); number of bunches (determined by the division of production in $\mathrm{kg} \mathrm{m}^{-2}$ per $100 \mathrm{~g}$, corresponding to 
the weight of the sauce in the supermarket of Mossoró, Northeastern Brazil); dry mass production (was obtained from a forced-air heating oven at $65{ }^{\circ} \mathrm{C}$, to constant mass and expressed in $\mathrm{kg} \mathrm{m}^{-2}$ ), Oil content (It was defined by the ratio between the mass in grams of essential oil by the mass of dry leaves inserted into the distillation flask $\times 1000$, being expressed in $\mathrm{g} \mathrm{kg}^{-1}$ ) and Oil production (It was determined by the oil content in $\mathrm{g} \mathrm{kg}^{-1} \mathrm{x}$ the production of dry mass in $\mathrm{kg} \mathrm{m}^{-}$ 2 , being expressed in $\mathrm{g} \mathrm{m}^{-2}$ ).

For the determination of oil content and yield, dry leaves were used, as recommended by Martins (2000), which states that the water content in the leaves, after drying, allows the vapor stream generated in the extractor to remove the volatile substances stored in cells, when compared to the green material. Guenther (1972) stated that due to the high moisture content in the plants, there is a strong tendency to agglutinate the material. This prevents the humidity to penetrate more easily or becoming uniform in plant tissues. In determining the essential oil content and yield, dry mass samples were subjected to hydrodistillation in a modified Clevenger apparatus for $1.5 \mathrm{~h}$, using $600 \mathrm{~mL}$ of distilled water in $1 \mathrm{~L}$ distillation flask (Simões et al., 2003).

\section{Statistics analysis}

An analysis of variance was performed on each feature of mint through the application ESTAT (Kronka and Banzato, 1995). For those measurements with quantitative nature (planting densities), the procedure of adjusting the response curve was performed using the Table Curve (Jandel Scientific, 1991) application.

\section{Conclusions}

The sowing density of 150 plants $\mathrm{m}^{-2}$ of mung bean provided production and number of mint sauces in the order of 2.63 $\mathrm{kg} \mathrm{m}^{-2}$ and 26.3 units $\mathrm{m}^{-2}$, respectively. For the forms of biomass management (incorporated and covered), no statistical difference was observed for the characteristics of the production of green mass, number of bunches, content and oil production of mint. The use of mung bean as a green manure is viable to be used by farmers in northeastern Brazil.

\section{Acknowledgements}

Special thanks to Jitirana (Merremia aegyptia L.) Research Group committed to the study of spontaneous species of the Caatinga Biome as fertilizer source and the Department of Agronomic and Forestry Sciences the Federal Rural SemiArid University (UFERSA), for the support in the conduction of the project.

\section{References}

Ambrosano EJ (2014) Produtividade de cana-de-açúcar em ciclos agrícolas consecutivos após pré-cultivo de espécies de adubos verdes. Revista de Agricultura. 89:232-251.

Carmo Filho F, Oliveira OF (1995) Mossoró: um município do semi-árido nordestino, caracterização climática e aspecto florístico. Mossoró: ESAM. 62 p. (Coleção Mossoroense, Série B).
Chagas JH, Pinto JEBP, Bertolucci SKV, Santos FM, Botrel PP, Pinto LBB (2011) Produção da hortelã-japonesa em função da adubação orgânica no plantio e em cobertura. Horticultura Brasileira. 29:412-417.

Cunha LMM, Linhares PCF, Neves APM, Almeida AMB, Pereira MFD, Assis JP, Sousa RP de, and Alves LS (2018) Agronomic efficiency of different quantitys of jitirana wixed with cattle manure in the intercropping of coriander with mint. Int J Develop Res. 8:18786-18792.

Deschamps C, Monteiro R, Machado MP, Bizzo H, Biasi LA (2012) Produção de biomassa, teor e composição do óleo essencial de mentha $x$ piperita L. Rev Bras de Plant Medicin. 14:12-17.

Empresa Brasileira de Pesquisa Agropecuária - Embrapa. (2006) Sistema brasileiro de classificação de solos. 2.ed. Rio de Janeiro: Embrapa, p.306.

Guenther E (1972) The essential oils. 6 ed. Huntington, N.Y.: R.E. Krieger, p.63.

Guerra AMN, Ferreira JBA, Lima TC, Costa ACM, Tavares PRF (2015) Cultivo consorciado de alface com plantas medicinais nas condições amazônicas. Revista Agrarian. 8:369-375.

Jandel S. (1991). Table curve: curve fitting software. Corte Madera, CA: Jandel Scientific. 280p.

Kottek M, Grieser J, Rudolf B, Rubel F (2006) Mapa mundial da classificação climática de Köppen-Geiger atualizada. Meteorologische Zeitschrift. 15: 259-263.

Kronka SN, Banzato DA (1995) Estat: sistema para análise estatística. Versão 2. 3.ed. Jaboticabal: Funep, 243p.

Linhares PCF (2013). Adubação verde como condicionadora do solo. Revista Campo e Negócios. 11:22-23.

Linhares PCF, Maracajá PB, Pereira MFS, Assis JP, and Sousa RP (2014) Roostertree (Calotropis procera) under different amounts and periods of incorporation on yield of coriander. Revista Verde de Agroecologia e Desenvolvimento Sustentável. 9:07-12.

Martins PM (2000) Influência da temperatura e velocidade do ar de secagem no teor e na composição química do óleo essencial de capim limão (Cymbopogum citratus (D.C.) STAPF). 77p. Dissertação (Mestrado- Área de Concentração em Plantas Medicinais) -Departamento de Engenharia Agrícola - Plantas Medicinais, Universidade Federal de Viçosa.

Neves APM, Linhares PCF, Souza RP, Assis JS, Neves AM, Cunha LMM, Almeida AMB, Pereira MFS, and Alves LS (2018) Successive crops of lettuce fertilized with bovine manure in the presence and absence of mung bean. Int J Develop Res. 08:19754-19760.

Oliveira ARMF (2010) Produção de óleo essencial de Mentha $x$ piperita var. citrata sob diferentes condições de manejo. (Dissertação de mestrado) Universidade Estadual de Santa Cruz. 68p.

Rêgo LGS da, Martins CM, Silva EF da, Silva JJA da, Lima RNS (2016) Pedogenesis and soil classification of na experimental farm in Mossoró, state of Rio Grande do Norte, Brasil. Revista Caatinga. Mossoró. 29:1036-1042.

Rezende BLA, Cecilio Filho AB, Catelan F, Martins MIE (2005) Análise econômica de cultivos consorciados de alface americana $x$ rabanete: um estudo de caso. Horticultura Brasileira. 23:853- 858 . 
Simões CMO (2003). Farmacognosia: da planta ao medicamento. 5. ed. Porto Alegre/Florianópolis: Editora UFRGS/Editora UFSC, $1102 \mathrm{p}$.

Souza CM, Pires FR, Partelli FL, Assis RL (2012) Adubação verde e rotação de culturas. 108p. Viçosa- MG: Ed. UFV.

Taiz L, Zeiger E (2017) Fisiologia e Desenvolvimento Vegetal. 6.ed. Porto Alegre: Artmed, 888p.

Tavares Junior JB, Santos TM, Souza EGA de, Menezes CHSG, and Soares CS (2015) Production of fodder for green manuring in the Paraíba Agreste. (Produção de fabáceas para adubação verde no agreste paraibano), 11:47-58.
Valmorbida J, Boaro CFS, Marques MO, Ferri AF (2006) Rendimento e composição química do óleo essencial de Mentha piperita L. cultivada em solução nutritiva com diferentes concentrações de potássio. Revista Brasileira de Plantas Medicinais. 8:56-61.

Vicente EC, Maia E, D'oliveira OS (2008) Produção de plantas medicinais adubadas com torta de filtro. Iniciação Científica Cesumar. 10:07-12.

Wildung MR, Croteau RB (2005) Genetic engineering of peppermint for improved essential oil composition and yield. Transgenic Resource. 14:365-72. 